\title{
Using website stickiness strategy to stick online readers : Web-based RPG Reading
}

\author{
Chi-Lung Lee \\ Director of Information Center \\ The Affiliated Senior High School of National Taiwan Normal University \\ Taiwan, ROC \\ Hsi-Peng Lu \\ Professor of Department of Information Management \\ National Taiwan University of Science and Technology \\ Taiwan, ROC \\ Judy Chuan-Chuan Lin \\ Professor of Department of Computer and Information Science \\ SooChow University \\ Taiwan, ROC
}

\begin{abstract}
In this study, we would like the readers to conduct online-reading using the method of role-playing. We chose the Journey to the West, one of China's four greatest classic literatures, as the material in this experiment. The readers will take on the role of the main hero of the book, Sun-wu-kong, while reading, experiencing, and exploring the story. We wish to discuss topics relevant to website stickiness and characteristics of online game and in turn to understand the acceptance of Web-based RPG Reading style.
\end{abstract}

Keywords: Online Reading, Online Role Play Game, Stickiness

\section{Introduction}

Up to July 2005, the growth of Internet users in Taiwan has reached to $14,660,000$ people approximately, and over 2,700,000 people are online readers. It shows that the reading behavior in Taiwan had gradually shifted onto the Internet. People living within a digital era had formed a habit to read online (Chang, 2006). But Online Reading is no longer a linear activity, it's a sampling process, and could jump from one publication to another easily (Ojala, 2000).

To online gamers, online games are extremely attractive, and online gaming websites seem to be able keep gamers on their sites for long hours. As for online reading websites, they seem to be less attractive and less able to make users "stick" to them for long hours. Through theories related to intrinsic motivation for reading, website stickiness and 
characteristics of online games, we attempt to determine the functions that an online reading website which has website stickiness should possess in the wish of finding the functions that would attract readers who would repeatedly access, or even stick to the reading website.

In this study, we wish to discuss topics relevant to reading motivation, website stickiness and characteristics of online games, and in turn to understand the acceptance of Web-based RPG Reading style. In other words, we will design the questionnaire to collect the opinions of the online readers to understand users' opinions and level of acceptance of Webbased RPG reading style.

\section{Relevant Theories}

\section{Theories on Reading}

Scholars such as Bond (1994) have defined reading as identifying written symbols which stimulate a reader to retrieve the previously learned meaning of the symbols. In other words, the acquisition of the meaning of written symbols must be achieved by a reader who recalls or manipulates the pre-existing concepts. Bond divides reading into two procedures: decoding and the acquisition of meaning. Alexander and Healthington (1988) believe reading is a meaningful process with the purpose of acquiring the meaning of a passage.

According to Sweet and Guthrie (1996), the extrinsic motivations for reading include conformity, identification, competition, and job avoidance, all of which are powerful attractors for children in the initial stage of learning as they provoke children's temporary attention and in-turn their effort. Despite its powerful attraction however, extrinsic motivation is not useful in terms of changing children's fundamental reading patterns since the activities provoked by the activities would disappear when extrinsic motivations or reinforcements disappear. Intrinsic motivation includes involvement, social interaction, challenge, and curiosity, and is a powerful and long-lasting support for reading activities. It helps individuals to maintain long-hours of reading, become good readers, and spontaneously develop or acquire more strategies that facilitate reading.

The questionnaire survey on reading motivations conducted by Wigfield and Guthrie (1997) shows that children's intrinsic motivation for reading is better at predicting the quantity and width of reading than extrinsic motivation does. In order to help students develop intrinsic motivations, the teacher must organize a set of teaching plans that combines reading, writing, science, and social studies and provide opportunities for children to independently define their interests, choose texts, and connect the concepts in different types of texts through self-guidance based on their involvement and curiosity (Sweet \& Guthrie, 1996).

From the intrinsic motivation for reading that was proposed by Pintrich, we can understand that there are complicated reading motivations for each individual, and intrinsic motivations for reading are an important driving force for readers to be willing to engage in reading and be challenged by texts. Pintrich (1987) believe that a learner's learning process should include three intrinsic motivations: value, expectation, and affect. They are explained below: (1) Value: This refers to a learner's reason for engaging in a learning activity, the perceived importance, and values. This includes a student's goal orientation and work value. 
(2) Expectation: This includes a learner's control belief, the belief that he/she can successfully complete a job, and self-efficacy. (3) Affect: This includes a learner's emotional reactions towards leaning and his/her self-evaluation through self-value or self-respect.

\section{Theories on Flow}

In 1975, Csikszentmihalyi (1975) proposed the Flow Theory, which indicates that if a person engaging in an activity is fully concentrated, he/she will filter out other irrelevant perceptions and enter the "flow" status.

Based on the Flow Theory, Trevino and Webster (1992) believe the interaction between a user and CMC (Computer-mediated communication) is a form of game and exploration. The Flow Theory believes that the flow is a user's experience of being deeply involved in games and explorations and such a pleasant experience encourages the user to engage repeatedly.

When interpreting the interaction between a human and a computer with the Flow Theory and treating such interaction as a fun and explorative experience, Hoffman and Novak (1996) propose that the flow occurs in internet surfing when (1) the interaction with the computer is smooth; (2) the experience is intrinsically enjoyable; (3) the experience is accompanied with a loss of self-consciousness; and (4) the experience is self-reinforcing. In order to achieve the flow in an activity, the user must achieve a balance between the skills he/she possesses and the level of challenge the activity offers, and both of these two aspects must be at a certain level. It is also proposed that certain positive benefits are seen during the flow stage, including increased consumer learning, exploratory behaviors, and positive affect.

Webster (1993) proposes that the flow experience can be measured in four dimensions: (1) The user's perceived control with the computer; (2) the user's perceived level of concentration; (3) the level of arousal of the user's curiosity; (4) how interesting the user thinks the interaction is (Webster, Trevino and Ryan 1993).

In the study on users' acceptance of the internet, Moon and Kim (2001) combined perceived playfulness with the Flow Theory in order to extend the application of the Technology Acceptance Model. In the study on online gamers, Hsu and Lu (2003) also combined Technology Acceptance Model with the Flow Theory and social factors in order to analyze the reasons that draw gamers to online games.

\section{Theories on Online Game and Stickiness}

Online games have certain characteristics that attract gamers to go online, access the games, and stick to the games (Chen, 2004). According to the literature discussion, we find that these characteristics include: (1) Role-playing: Gamers play their own roles and interact with other in all types of games, much like wearing masks online. (2) Virtual community: Communities exist in online games where human interactions are possible. (3) Tele-presence: Online games have the sense of "tele-presence," which includes personal-presence, socialpresence, and environment-presence. (4) Real-time, multi-player interactions: Real-time, multi-player interactions facilitate exchanges among members of a virtual community and allow sufficient interactions. 
The definition of Stickiness is the ability of websites to attract and retain customers (Zott et al. 2000). Reichheld and Schefter (2000) believed that web user's willingness to return is a strong indicator of website loyalty. According to literature discussion, we find that website stickiness is comprised of three main aspects (Lin, 2006), which are: (1) The user's positive attitude toward the website. (2) The user's high level of trust in the website. (3) The website's high-quality content.

\section{Web-based Online Reading}

According to the related theories, we proposed a framework of Web-based Online Reading as follows.

\begin{tabular}{|c|c|c|c|}
\hline $\begin{array}{c}\text { online game } \\
\text { characteristics }\end{array}$ & $\begin{array}{c}\text { Functions of } \\
\text { Web-based } \\
\text { RPG Reading }\end{array}$ & $\begin{array}{c}\text { Description of } \\
\text { Function }\end{array}$ & $\begin{array}{c}\text { Function of } \\
\text { Corresponding Web- } \\
\text { based RPG Reading }\end{array}$ \\
\hline Role Playing & $\square$ & $\begin{array}{c}\text { The reader plays an } \\
\text { important role and } \\
\text { enters the world in the } \\
\text { book. }\end{array}$ & $\begin{array}{c}\text { Role-playing reading } \\
\text { mechanism. }\end{array}$ \\
\hline $\begin{array}{c}\text { Virtual } \\
\text { (book clubs })\end{array}$ & $\square$ & $\begin{array}{c}\text { Provides readers with a } \\
\text { discussion community } \\
\text { where each person's } \\
\text { reading options can be } \\
\text { viewed. }\end{array}$ & $\begin{array}{c}\text { The readers who have } \\
\text { read the same books } \\
\text { are put in a virtual } \\
\text { community. }\end{array}$ \\
\hline $\begin{array}{c}\text { Long-distance } \\
\text { participation }\end{array}$ & $\square$ & $\begin{array}{c}\text { RPG Reading does not } \\
\text { provide this function } \\
\text { since most of the } \\
\text { functions here are } \\
\text { built for 3D gaming. }\end{array}$ & $\begin{array}{c}\text { None. } \\
\text { Real-time }\end{array}$ \\
$\begin{array}{c}\text { multiplayer } \\
\text { interaction }\end{array}$ & $\square$ & $\begin{array}{c}\text { Provides a human- } \\
\text { machine interaction } \\
\text { mechanism. }\end{array}$ & $\begin{array}{c}\text { Human-machine } \\
\text { interaction } \\
\text { mechanism. }\end{array}$ \\
\hline
\end{tabular}

\section{Questionaries}

In this study, we would like the readers to conduct online-reading using the method of role-playing. We chose the Journey to the West, one of China's four greatest classic literatures, as the material in this experiment. The readers will take on the role of the main hero of the book, Sun-wu-kong, while reading, experiencing, and exploring the story. Use a questionnaire to find out whether the reading style of google books (place scanned pages on the Internet for viewing) or Web-based RPG Reading is more attractive to readers.

Some Questions of this study was adopted Likert Scale method to design user questionnaires. Responses were measured with a five-point scale ( $1=$ Strongly Disagree, $2=$ Disagree, 3= Undecided, 4= Agree, and $5=$ Strongly Agree). Thus a total numerical value can be calculated from all the responses. Higher item scores indicate greater Agree. 
The user questionnaires and results are as follows.

\begin{tabular}{|c|c|c|c|}
\hline Question & Option & Results & $\%$ or Mean \\
\hline $\begin{array}{l}\text { 1.Do you enjoy playing online RPG } \\
\text { games? }\end{array}$ & $\begin{array}{l}\square \text { Yes } \\
\square \text { No }\end{array}$ & $\begin{array}{l}58 \\
13\end{array}$ & $82 \%$ \\
\hline $\begin{array}{l}\text { 2. How much time do you spend on } \\
\text { online RPG games per week? }\end{array}$ & $\begin{array}{l}\square \text { Less than } 1 \mathrm{hr} . \\
\square 1 \sim 2 \mathrm{hr} . \\
\square 2 \sim 5 \mathrm{hrs} . \\
\square 5 \mathrm{hrs} \text {. or more. }\end{array}$ & $\begin{array}{c}30 \\
17 \\
15 \\
9\end{array}$ & None \\
\hline $\begin{array}{l}\text { 3. Do you enjoy reading extracurricular } \\
\text { materials? }\end{array}$ & $\begin{array}{l}\square \text { Yes } \\
\square \text { No }\end{array}$ & $\begin{array}{c}63 \\
8\end{array}$ & $89 \%$ \\
\hline $\begin{array}{l}\text { 4. How much time do you spend on } \\
\text { reading extracurricular materials? }\end{array}$ & $\begin{array}{l}\square \text { Less than } 1 \mathrm{hr} . \\
\square 1 \sim 2 \mathrm{hr} . \\
\square 2 \sim 5 \mathrm{hrs} . \\
\square 5 \mathrm{hrs} \text {. or more. }\end{array}$ & $\begin{array}{l}18 \\
21 \\
15 \\
17\end{array}$ & None \\
\hline $\begin{array}{l}\text { 5. Would you be willing to read a book } \\
\text { through role-playing? }\end{array}$ & $\begin{array}{l}\square \text { Yes } \\
\square \text { No }\end{array}$ & $\begin{array}{c}68 \\
3\end{array}$ & $96 \%$ \\
\hline $\begin{array}{l}\text { 6. Do you agree that the reading style of } \\
\text { role-playing is more attractive and } \\
\text { would draw you back to a book when } \\
\text { compared to the style of text-only? } \\
\text { (e.g., playing the role of Sun-wu-kong } \\
\text { in the Journey to the West?) }\end{array}$ & $\begin{array}{l}\square \text { Strongly agree } \\
\square \text { Agree } \\
\square \text { No comment } \\
\square \text { Disagree } \\
\square \text { Strongly disagree }\end{array}$ & $\begin{array}{c}14 \\
34 \\
22 \\
1 \\
0\end{array}$ & 3.86 \\
\hline $\begin{array}{l}\text { 7. Do you agree that the reading style of } \\
\text { role-playing is more attractive when } \\
\text { compared to the style of text-only? }\end{array}$ & $\begin{array}{l}\square \text { Strongly agree } \\
\square \text { Agree } \\
\square \text { No comment } \\
\square \text { Disagree } \\
\square \text { Strongly disagree }\end{array}$ & $\begin{array}{c}18 \\
32 \\
20 \\
1 \\
0\end{array}$ & 3.94 \\
\hline
\end{tabular}

\section{Result \& Conclusion}

In this study, we wish to discuss topics relevant to internet attraction and features of online games, thus we conduct an experimental questionnaire survey to understand how readers feel about Web-based RPG Reading.

We sent out 80 copies of questionnaires to senior high school students and retrieved 71 valid copies. Compare the Question1 and Question3, We found a surprised phenomenon that is readers prefer reading extracurricular materials to playing online RPG games. The enjoy rate is $89 \%$ and $82 \%$ respectively.

In the Question5, we found $96 \%$ of readers be willing to read a book through roleplaying. It's really good news to our research hypothesis. Finally, the result of Question6 and Question7 inspire us. Let us have more confidence with our research hypothesis. Using Webbased RPG Reading style to read will draw readers to a book more easily. We have discovered that Web-based RPG Reading is indeed more attractive and improves the readers' 
intrinsic motivations for reading, and the readers were also very willing to experiment with such new reading style.

In Our Web-based RPG reading hypothesis, we will arrange simple multiple-choice questions based on fun and interesting plots in the story to draw the readers into the world in the book. These questions are not designed to confuse the readers but to help them be immersed in the story and become the important the roles that face the situations in the story, and the end result is improved sense of challenge and curiosity.

\section{Future Work}

Based on the findings, we can further develop reading websites that allow roleplaying and perhaps even promote the flow experience in readers who can also be challenged and to acquire new knowledge. Through such new reading pattern, we wish to improve readers' interest in reading and enhance the attractiveness of online reading in order to promote such activity throughout the society.

\section{Reference}

Alexander, J E., \& Heathington, B. S. (1988). Assessing and correcting classroom reading problem. Glenview, Illinoies: Scott, Foresman and Company.

Bond, G. L., Tinker, M. A., Wasson, B. B., \& Wasson, J. B. (1994) .Reading difficulties : Their diagnosis and correction(7th ed). Boston : Alleyn and Bacon.

Chen, Y.A. (2004). The on-line game charm: plays the family take the specific weight as an example. NanHua University.

Csikszentmihalyi, M. (1975). Beyond Boredom and Anxiety: Experiencing Flow in Work and Play. Jossey-Bass Inc, CA.

Hoffman, D.L. and Novak, T.P., (1996). Marketing in Hypermedia Computer-Mediated Environments: Conceptual Foundations. Journal of Marketing, Vol.60, 50-68.

Hsu, C.L. and Lu, H.P., (2004). Why do people play on-line games? An extended TAM with social influences and flow experience. Information and Management, vol 41 , no 7, 853-868.

Lin, Judy C.C., (2007). Online stickiness: its antecedents and effect on purchasing intention, Behaviour \& Information Technology, 1-10.

Moon, J.W., and Kim, Y.G., (2001). Extending the TAM for a World-Wide-Web context. Information \& Management, vol 38, no 4, 217-230.

Ojala, M. (2000). Online Reading as a Nonlinear Activity. Retrieved from EContent http://www.ecmag.net/EC2000/editorial10.html.

Pintrich, P.R., (1987). Motivated learning strategies in the college classroom. Paper presented at the American Educational Research Association Convention, Washington, D.C.

Reichheld, F.F. and Schefter, F.(2000). E-Loyalty: Your secret weapon on the web. Harvard Business Review, July - August, 105-113. 
Sweet, A.P., and Guthrie, J.T., (1996). How Children's Motivations Relate to Literacy Development and Instruction. Reading Teacher, 49(8), 660-662.

Trevino, L.K., and Webster. J., (1992). Flow in Computer-Mediated Communication: Electronic Mail and Voice mail evaluation and impacts, Communication Research, Vol.19, No.5, 539-573.

Webster, J., Trevino L.K. and Ryan L., (1993). The dimensionality and correlates of Flow in human-computer interactions, Computers in Human Behavior, Vol.9, 411-426.

Wigfield, A., and Guthrie, J.T. (1997). Relations of Children's Motivation for Reading to the Amount and Breadth of Their Reading. Journal of Educational Psychology, 89(3), 420-432.

Zott, C., Amit, R. and Donlevy, J. (2000). Strategies for value creation in e-commerce: best practice in Europe. European Management Journal, 18, 463-475.

\section{Author Note:}

Lee, Chi-Lung, Director of Information Center at the Affiliated Senior High School of National Taiwan Normal University, has published two SSCI journal papers and presented papers at the international levels. He has two master degrees. One is Information and Computer Education at National Taiwan Normal University and the other is Business and Management at National Chiao Tung University. His major interest lies in developing information systems just like web-based learning system or knowledge management system that contribute to students learning and school administration.

\section{Statement of Originality}

This statement certifies that the paper above is based upon original research undertaken by the author and that the paper was conceived and written by the author(s) alone and has not been published elsewhere. All information and ideas from others is referenced. 